\title{
Caffeine as a Protective Factor in Dementia and Alzheimer's Disease
}

\author{
Marjo H. Eskelinen ${ }^{\mathrm{a}, *}$ and Miia Kivipelto ${ }^{\mathrm{a}, \mathrm{b}, *}$ \\ ${ }^{a}$ University of Eastern Finland, School of Medicine, Institute of Clinical Medicine - Neurology, Kuopio, Finland \\ ${ }^{\mathrm{b}}$ Aging Research Center (ARC), Karolinska Institutet, Stockholm, Sweden
}

\begin{abstract}
Caffeine has well-known short-term stimulating effects on central nervous system, but the long-term impacts on cognition have been less clear. Dementia and Alzheimer's disease (AD) are rapidly increasing public health problems in ageing populations and at the moment curative treatment is lacking. Thus, the putative protective effects of caffeine against dementia/AD are of great interest. Here, we discuss findings from the longitudinal epidemiological studies about caffeine/coffee/tea and dementia/AD/cognitive functioning with a special emphasis on our recent results from the Cardiovascular Risk Factors, Aging and Dementia (CAIDE) study. The findings of the previous studies are somewhat inconsistent, but most studies (3 out of 5) support coffee's favorable effects against cognitive decline, dementia or AD. In addition, two studies had combined coffee and tea drinking and indicated some positive effects on cognitive functioning. For tea drinking, protective effects against cognitive decline/dementia are still less evident. In the CAIDE study, coffee drinking of 3-5 cups per day at midlife was associated with a decreased risk of dementia/AD by about $65 \%$ at late-life. In conclusion, coffee drinking may be associated with a decreased risk of dementia/AD. This may be mediated by caffeine and/or other mechanisms like antioxidant capacity and increased insulin sensitivity. This finding might open possibilities for prevention or postponing the onset of dementia/AD.
\end{abstract}

Keywords: Alzheimer's disease, caffeine, coffee, dementia, epidemiology

\section{INTRODUCTION}

Caffeine (1,3,7-trimethylxanthine) is present in many dietary sources consumed around the world, i.e., in coffee, tea, cocoa beverages, candy bars, and soft drinks. The amount of caffeine ranges quite widely between these various food items, with coffee representing a major source of intake $(71-220 \mathrm{mg}$ caffeine $/ 150 \mathrm{ml}$ ) [1]. In tea, the content of caffeine is 32$42 \mathrm{mg} / 150 \mathrm{ml}$, in cola $32-70 \mathrm{mg} / 330 \mathrm{ml}$ and in cocoa $4 \mathrm{mg} / 150 \mathrm{ml}$.

${ }^{*}$ Correspondence to: Marjo Eskelinen, MSc, University of Eastern Finland, School of Medicine, Institute of Clinical Medicine, Neurology, P.O. Box 1627, 70211 Kuopio, Finland. Tel.: +358 40 355 2019/ +358 503634 625; Fax: +358 1716 2048; E-mail: Marjo.Eskelinen@uef.fi. Miia Kivipelto, MD, PhD, Aging Research Center, NVS, Karolinska Institutet, Gävlegatan 16, 11330 Stockholm, Sweden. Tel.: +46 7399409 22; Fax: +46 8690 5954; E-mail: Miia.Kivipelto@ki.se.
Coffee is widely consumed globally. According to international statistics, the highest per capita coffee consumption in the world is among Finns with $12.0 \mathrm{~kg}$ in year 2007 , followed by $9.9 \mathrm{~kg}$ among Norwegians, and $8.7 \mathrm{~kg}$ among Danes [2]. However, the content of caffeine per cup varies largely according to the serving size $(50-190 \mathrm{ml})$, the preparation method (boiled, filtered, percolated, espresso, instant), and the type of the coffee used (Arabica or Robusta) [1]. Depending on the preparation method, the caffeine content of a cup of coffee ranges from $0.6-3.3 \mathrm{mg} / \mathrm{ml}$ for espresso, $0.7-1.1 \mathrm{mg} / \mathrm{ml}$ for boiled or filtered coffee and $0.2-0.6$ $\mathrm{mg} / \mathrm{ml}$ (up to as much as $1.0 \mathrm{mg} / \mathrm{ml}$ ) in instant coffee. Arabica is the most consumed type of coffee throughout the world, representing in most countries 70\%-100\% (100\% in Finland and Sweden) of the whole of coffee consumed. However, the average content of caffeine is about twice as high in Robusta as in Arabica coffee. Thus, in a standard $150 \mathrm{ml}$ cup, the content of caffeine ranges from 131-220 mg/cup for Robusta and from 71-120 mg/cup for Arabica coffee. 
Tea, a product made from leaf and bud of the plant Camellia sinensis, is, after water, the most consumed drink in the world with per capita mean consumption of $120 \mathrm{ml} /$ day [3]. Teas are classified into three major types depending on the manufacturing process: nonfermented green tea, semi-fermented oolong tea, and fermented black and red (Pu-Erh) teas. Approximately $76-78 \%$ of the tea produced and consumed is black tea, $20-22 \%$ is green tea, and less than $2 \%$ is oolong tea. Black tea is consumed principally in Europe, North America and North Africa (except Morocco), green tea in China, Japan, Korea and Morocco, and oolong tea in China and Taiwan. In the USA, $80 \%$ of the tea consumed is black iced tea.

The short-term central nervous system stimulating effects of caffeine are well known [4], but the long-term impact has been more unclear. Low to moderate doses of caffeine (50-300 mg) cause the most notable behavioral effects including increased alertness, energy, and ability to concentrate, but higher doses can cause negative effects such as anxiety, restlessness, insomnia, and tachycardia [1].

The aim of this article is to provide an overview of the previously published longitudinal epidemiological studies, taking into account the distinctions between coffee/ tea/caffeine intake and dementia/Alzheimer's disease (AD)/cognitive functioning. We will briefly present these studies with a special focus on our recent results from the Cardiovascular Risk Factors, Aging and Dementia (CAIDE) study. Finally, possible explanations and mechanisms behind these findings will be shortly discussed.

\section{MATERIALS AND METHODS}

\section{Previous longitudinal studies}

We did a Pubmed search using search words caffeine/coffee/ tea and dementia/AD/cognition/cognitive function/cognitive performance (limits: English language, original articles, human studies). Deadline for study inclusion was October 31, 2009. For a candidate study to be selected, the study needed to use longitudinal analyses, have adequate information about methods and analyses used, and be published in a peer-reviewed journal. We identified nine studies altogether that fulfilled the inclusion criteria and were included to this review. Study designs, sample sizes, exposure and outcome measures, confounding factors, and main results of these studies are presented in Table 1. The stud- ies included were: the Canadian Study of Health and Aging (CSHA), the Maastricht Aging Study (MAAS), the Honolulu-Asia Aging Study (HAAS), the Kame Project, the Finland, Italy and the Netherlands Elderly (FINE) Study, the Three City Study, the Singapore Longitudinal Ageing Studies (SLAS) cohort, the Cardiovascular Risk Factors, Aging and Dementia (CAIDE) study and Finnish Twin Cohort Study. All studies had population-based samples and most of them included both women and men (with the exception of HAAS and FINE that included only men). The sample sizes in these studies were large varying from 676 to 7017 persons. Follow-up times varied from 16 months to 30 years. Systematic review and meta-analysis of all studies investigating the association between caffeine and dementia/cognitive decline is presented by Santos et al. [5] in this issue.

\section{CAIDE study}

The participants of the Cardiovascular risk factors, Aging and Dementia (CAIDE) study were randomly selected from survivors of population-based random samples firstly studied within the North Karelia Project and the FINMONICA study in 1972, 1977, 1982, or 1987 (baseline, midlife visit) [6]. A more detailed description of the sampling has been described earlier [6-8]. Altogether $1409(71 \%)$ individuals of a random sample of 2000 survivors (age: 65-79 years in the end of year 1997, place of residence: Eastern Finland) completed the follow-up examination (late-life visit) during 1998 after a mean follow-up time of 21 years.

The survey methods were carefully standardized and complied with international recommendations [9]. In brief, the survey included an exhaustive selfadministered questionnaire (on average 135 items) on health behavior (e.g., dietary habits), health status, and medical history filled in at home. The consumption of coffee and tea were assessed quantitatively with a questionnaire at the midlife examination. Coffee drinking was categorized into three groups: 0-2 cups (low), 3-5 cups (moderate) and $>5$ cups (high) per day. Further, the question concerning tea consumption was dichotomized into those not drinking tea ( 0 cup/day) vs. those drinking tea ( $\geqslant 1$ cup/day). Further, systolic (SBP) and diastolic (DBP) blood pressure, height and weight were measured, body mass index (BMI) was calculated, and a venous blood sample was taken to determine serum cholesterol.

Cognitive status was assessed using a three-step protocol for the diagnosis of dementia (a screening, a 


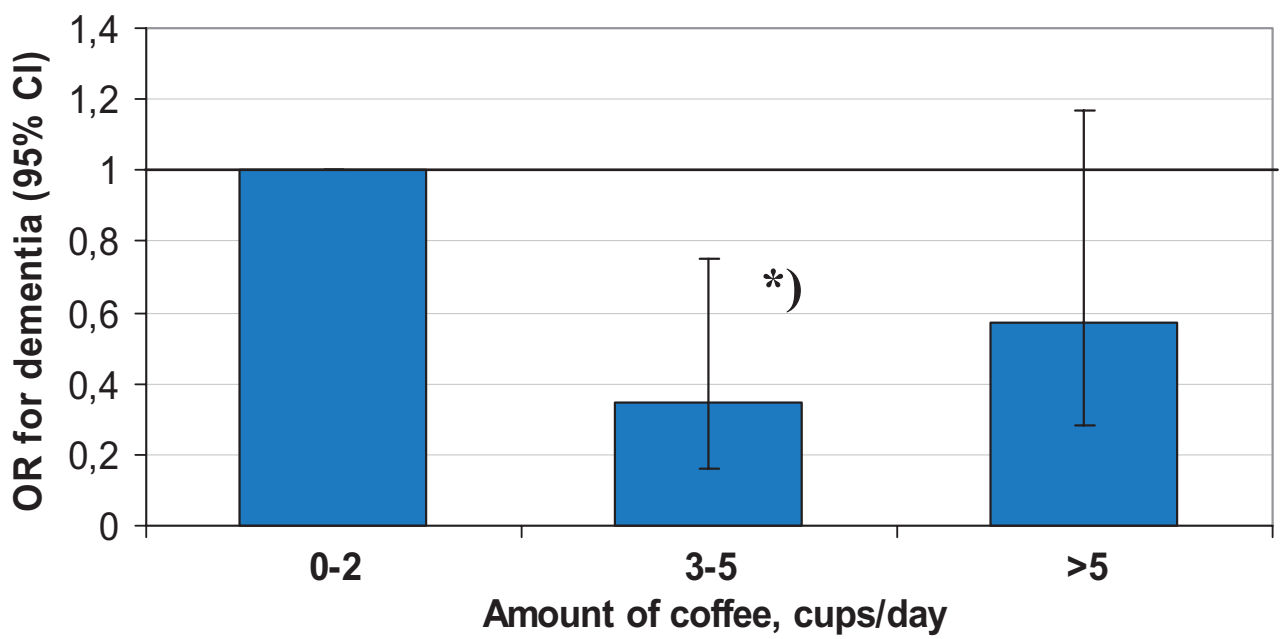

Fig. 1. Association between coffee drinking and dementia. Adjusted for age, gender, education, follow-up time, community of residence, midlife smoking, SBP, serum total cholesterol, BMI, and physical activity (model 2). *) $p \leqslant 0.05$.

clinical and a differential diagnostic phase) at the reexamination. The diagnosis of dementia was based on DSM-IV criteria [10] and the probable and possible AD on the NINCDS-ADRDA criteria [11]. A total of 61 persons met the diagnosis of dementia, out of which 48 had AD. The number of demented persons increased to 117 when diagnoses derived from the patient records for the non-participants in the follow-up examination were taken into account.

Logistic regression models were used to analyze independent effect of coffee or tea drinking to the risk of dementia and AD so that the lowest category served as the reference group. Possible confounders were added in blocks in the analyses (see results).

\section{RESULTS}

\section{Previous longitudinal studies}

The nine longitudinal studies investigating the association between coffee and/or tea consumption/caffeine intake and dementia/AD or cognitive decline (Table 1) have showed partly inconsistent results. In the Canadian Study of Health and Aging (CSHA) among $\geqslant 65$ years old persons, daily coffee drinking decreased the risk of $\mathrm{AD}$ by $31 \%$ during a 5-year follow-up [12]. In the Finland, Italy and the Netherlands Elderly (FINE) Study among elderly men, drinking three cups of coffee per day was associated with the least 10year cognitive decline [13]. However, the latest data from the Finnish Twin Cohort Study showed no rela- tion between coffee consumption and cognitive performance/MCI/dementia over a 28-year period [14].

In the Maastricht Aging Study (MAAS) among 2481 years old persons, habitual caffeine intake was associated with faster locomotor speed, but not with cognitive decline during a 6-year period [15]. In the Three City Study among $\geqslant 65$ years old persons, over three cups of caffeine per day was associated with less decline in verbal cognitive functioning and to a lesser extent in visuospatial memory among women but not among men. No relation was found between caffeine consumption and dementia risk over a 4-year period [16].

Tea drinking was not associated with a reduced risk of dementia/AD neither in the Honolulu-Asia Aging Study (HAAS) among 45-68 years old persons with $>$ 30.2-year follow-up [17] nor in the Kame Project among $\geqslant 65$ years old persons during $>6.3$-year follow-up [18]. In the Singapore Longitudinal Ageing Studies (SLAS) cohort among $\geqslant 55$ years old persons, regular tea drinking was associated with a reduced risk of cognitive decline during a 1-2 year period [19].

\section{CAIDE results}

Recent results from our Cardiovascular Risk Factors, Aging and Dementia (CAIDE) study indicated that drinking three to five cups of coffee per day at midlife (mean age 50.4 years) was associated with a decreased risk of dementia by $65 \%$ (Fig. 1) and AD by $64 \%$ (Fig. 2) later in life during a 21-year follow-up [8]. At midlife, majority of the participants $(45.6 \%)$ consumed daily moderate (3-5 cups) amounts of coffee, 
Table 1

The major prospective studies examining the association between coffee/tea/caffeine intake and dementia/AD/cognitive function

\begin{tabular}{|c|c|c|c|c|c|}
\hline Study & Sample & Study design & $\begin{array}{l}\text { Coffee/tea/caffeine } \\
\text { intake }\end{array}$ & Covariates & Outcome and results \\
\hline $\begin{array}{l}\text { Lindsay et } \\
\text { al., 2002 [12] } \\
\text { CSHA, } \\
\text { Canada }\end{array}$ & $\begin{array}{l}\mathrm{N}=4088 \\
\geqslant 65 \text { years } \\
60.7 \% \text { women }\end{array}$ & $\begin{array}{l}\text { Longitudinal, } \\
\text { 5-year follow- } \\
\text { up }\end{array}$ & $\begin{array}{l}\text { Daily coffee or tea } \\
\text { drinking }\end{array}$ & Age, gender, education & $\begin{array}{l}\text { Decreased risk of } \mathrm{AD} \text { by } 31 \% \\
\text { with daily coffee drinking. Ns } \\
\text { for flavonoid intake from tea } \\
\text { and } \mathrm{AD}\end{array}$ \\
\hline $\begin{array}{l}\text { van Boxtel et } \\
\text { al., } 2003 \text { [15] } \\
\text { MAAS, the } \\
\text { Netherlands }\end{array}$ & $\begin{array}{l}\mathrm{N}=1376, \\
24-81 \text { years, } \\
\text { (mean: } 50.2 \text { years), } \\
48.5 \% \text { women }\end{array}$ & $\begin{array}{l}\text { Longitudinal, } \\
\text { 6-year follow- } \\
\text { up }\end{array}$ & $\begin{array}{l}0,1-3,4-6,7-10, \\
>10 \text { cups of coffee } \\
\text { or tea/d; total caffeine } \\
\text { intake calculation ac- } \\
\text { cording to industrial } \\
\text { standards. }\end{array}$ & $\begin{array}{l}\text { Age, gender, education, } \\
\text { housing, occupation, sm- } \\
\text { oking, alcohol consump- } \\
\text { tion, perceived health }\end{array}$ & $\begin{array}{l}\text { Faster locomotor speed with } \\
\text { habitual caffeine intake. } \\
\text { Ns for cognitive decline }\end{array}$ \\
\hline $\begin{array}{l}\text { Laurin et al., } \\
2004 \text { [17] } \\
\text { HAAS, } \\
\text { Hawaii, USA }\end{array}$ & $\begin{array}{l}\mathrm{N}=2459, \\
45-68 \text { years, } \\
\text { (mean: } 52.4 \text { years), } \\
0 \% \text { women }\end{array}$ & $\begin{array}{l}\text { Longitudinal, } \\
>30.2 \text {-year } \\
\text { follow-up }\end{array}$ & $\begin{array}{l}\text { Mean intake of tea } \\
\text { (black and green); } \\
\text { flavonoid intake was } \\
\text { estimated from } 11 \\
\text { types of tea infusions }\end{array}$ & $\begin{array}{l}\text { Socio-demographic and } \\
\text { lifestyle factors, cardiovas- } \\
\text { cular risk factors, other di- } \\
\text { etary constituents, ApoE } \\
\varepsilon 4\end{array}$ & Ns for tea and dementia/AD \\
\hline $\begin{array}{l}\text { Dai et al., } \\
2006[18] \\
\text { Kame } \\
\text { Project, } \\
\text { Washington, } \\
\text { USA }\end{array}$ & $\begin{array}{l}\mathrm{N}=1589, \\
\geqslant 65 \text { years, } \\
\text { (mean: } 71.8 \text { years), } \\
54.4 \% \text { women }\end{array}$ & $\begin{array}{l}\text { Longitudinal, } \\
>6.3 \text {-year } \\
\text { follow-up }\end{array}$ & $\begin{array}{l}\text { Usual intake of tea } \\
\text { ( } 8 \text { frequency options } \\
\text { and } 3 \text { usual portion si- } \\
\text { zes; categorization to } \\
<1 / \mathrm{w}, 1-2 \mathrm{x} / \mathrm{w}, \geqslant \\
3 \mathrm{x} / \mathrm{w}\end{array}$ & $\begin{array}{l}\text { Age, gender, education, } \\
\text { physical activity, BMI, } \\
\text { baseline CASI score, ol- } \\
\text { faction diagnostic group, } \\
\text { total energy intake, intake } \\
\text { of SFAs, MUFAs and PU- } \\
\text { FAs, ApoE, smoking, alco- } \\
\text { hol drinking, supplementa- } \\
\text { tion of vitamins C, E and } \\
\text { multivitamin, dietary in- } \\
\text { take of vitamins C, E and } \\
\beta \text {-carotene }\end{array}$ & Ns for tea and $A D$ \\
\hline $\begin{array}{l}\text { van Gelder et } \\
\text { al., } 2007 \text { [13] } \\
\text { FINE, } \\
\text { Finland, } \\
\text { Italy and the } \\
\text { Netherlands }\end{array}$ & $\begin{array}{l}\mathrm{N}=676 \\
(101 \text { Finnish, } 239 \\
\text { Italian, } 336 \text { Dutch), } \\
\text { only elderly men }\end{array}$ & $\begin{array}{l}\text { Longitudinal, } \\
\text { 10-year follow- } \\
\text { up }\end{array}$ & $\begin{array}{l}0,1,2,3,4,>4 \text { cups } \\
\text { of coffee/d }\end{array}$ & $\begin{array}{l}\text { Age, education, coun- } \\
\text { try, alcohol consumption, } \\
\text { smoking status, physical } \\
\text { activity, baseline cognitive } \\
\text { functioning }\end{array}$ & $\begin{array}{l}\text { Men who consumed coffee } \\
\text { had a two times smaller 10- } \\
\text { y cognitive decline than non- } \\
\text { consumers. The smallest cog- } \\
\text { nitive decline ( } 0.6 \text { points) with } \\
\text { three cups of coffee per day }\end{array}$ \\
\hline $\begin{array}{l}\text { Ritchie et al., } \\
2007[16] \\
\text { Three City } \\
\text { Study, } \\
\text { France }\end{array}$ & $\begin{array}{l}\mathrm{N}=7017 \\
\geqslant 65 \text { years, } \\
59.8 \% \text { women }\end{array}$ & $\begin{array}{l}\text { Longitudinal, } \\
\text { 3.5-year follow- } \\
\text { up }\end{array}$ & $\begin{array}{l}\text { Daily caffeine intake } \\
\text { from coffee and tea }\end{array}$ & Age, gender, study center & $\begin{array}{l}\text { Fewer declines in verbal cogni- } \\
\text { tive functioning and to a lesser } \\
\text { extent in visuospatial memory } \\
\text { among women but not among } \\
\text { men with over three cups of caf- } \\
\text { feine per day. } \\
\text { Ns for dementia }\end{array}$ \\
\hline $\begin{array}{l}\text { Tze-Ping et } \\
\text { al., 2008 [19] } \\
\text { SLAS study, } \\
\text { Singapore }\end{array}$ & $\begin{array}{l}\mathrm{N}=1438 \\
\geqslant 55 \text { years, } \\
64 \% \text { women }\end{array}$ & $\begin{array}{l}\text { Longitudinal, } \\
\text { 1-2 year } \\
\text { follow-up } \\
\text { (median: } 16 \\
\text { months) }\end{array}$ & $\begin{array}{l}\text { Amount of tea cups: } \\
\text { never or rarely, }<1 / \mathrm{w} \text {, } \\
>1 / \mathrm{w} \text { but }<1 / \mathrm{d}, 1- \\
2 / \mathrm{d}, 3-5 / \mathrm{d}, 6-9 / \mathrm{d}, \geqslant \\
10 / \mathrm{d}\end{array}$ & $\begin{array}{l}\text { Age, gender, education, } \\
\text { smoking, alcohol con- } \\
\text { sumption, BMI, hyperten- } \\
\text { sion, diabetes, heart dis- } \\
\text { eases, stroke, depression, } \\
\text { ApoE } \varepsilon 4 \text {, physical activ- } \\
\text { ities, social and produc- } \\
\text { tive activities, vegetable } \\
\text { and fruit consumption, fish } \\
\text { consumption, daily cof- } \\
\text { fee consumption, baseline } \\
\text { MMSE score, interval be- } \\
\text { tween baseline and follow- } \\
\text { up }\end{array}$ & $\begin{array}{l}\text { Decreased risk of cognitive } \\
\text { decline with higher level of } \\
\text { tea consumption (especially for } \\
\text { black or oolong tea). } \\
\text { Ns for coffee and cognitive } \\
\text { decline }\end{array}$ \\
\hline
\end{tabular}


Table 1, continued

\begin{tabular}{|c|c|c|c|c|c|}
\hline Study & Sample & Study design & $\begin{array}{l}\text { Coffee/tea/caffeine } \\
\text { intake }\end{array}$ & Covariates & Outcome and results \\
\hline $\begin{array}{l}\text { Eskelinen et } \\
\text { al., 2009 [8] } \\
\text { CAIDE, } \\
\text { Finland }\end{array}$ & $\begin{array}{l}\mathrm{N}=1409 \\
\text { mean age: } \\
50.4 \text { years, } \\
62 \% \text { women }\end{array}$ & $\begin{array}{l}\text { Longitudinal, } \\
\text { 21-year follow- } \\
\text { up }\end{array}$ & $\begin{array}{l}0-2,3-5,>5 \text { cups of } \\
\text { coffee/d. } \\
0, \geqslant 1 \text { cups of tea/d. }\end{array}$ & $\begin{array}{l}\text { Age, gender, education, } \\
\text { follow-up, residence, mi- } \\
\text { dlife smoking, SBP, serum } \\
\text { total cholesterol, BMI, } \\
\text { physical activity. }\end{array}$ & $\begin{array}{l}\text { Decreased risk of dementia by } \\
65 \% \text { and } \mathrm{AD} \text { by } 64 \% \text { with daily } \\
\text { coffee drinking of } 3-5 \text { cups. Ns } \\
\text { for tea and dementia/AD }\end{array}$ \\
\hline $\begin{array}{l}\text { Laitala et al., } \\
2009 \text { [14] } \\
\text { Finnish Twin } \\
\text { Cohort } \\
\text { Study, } \\
\text { Finland }\end{array}$ & $\begin{array}{l}\mathrm{N}=2606, \\
\text { middle-aged twins } \\
\text { (mean age: } 46-52 \\
\text { years), } \\
48 \% \text { women }\end{array}$ & $\begin{array}{l}\text { Longitudinal, } \\
\text { 28-year follow- } \\
\text { up }\end{array}$ & $\begin{array}{l}0-3,3.5-8,>8 \text { cups } \\
\text { of coffee } / \mathrm{d}\end{array}$ & Education, age, gender & $\begin{array}{l}\text { Ns for coffee and cognitive per- } \\
\text { formance, MCI or dementia }\end{array}$ \\
\hline
\end{tabular}

Abbreviations: $\mathrm{AD}=$ Alzheimer's disease; $\mathrm{BMI}=$ body mass index; CAIDE = Cardiovascular Risk Factors, Aging and Dementia study; CASI $=$ Cognitive Abilities Screening Instrument; CSHA = Canadian Study of Health and Aging; FINE = Finland, Italy and the Netherlands Elderly Study; HAAS = Honolulu-Asia Aging Study; MAAS = Maastricht Aging Study; MCI = mild cognitive impairment; MUFA = monounsaturated fatty acid; Ns = not significant; PUFA = polyunsaturated fatty acid; SBP = systolic blood pressure; SFA $=$ saturated fatty acid; SLAS $=$ Singapore Longitudinal Ageing Studies.

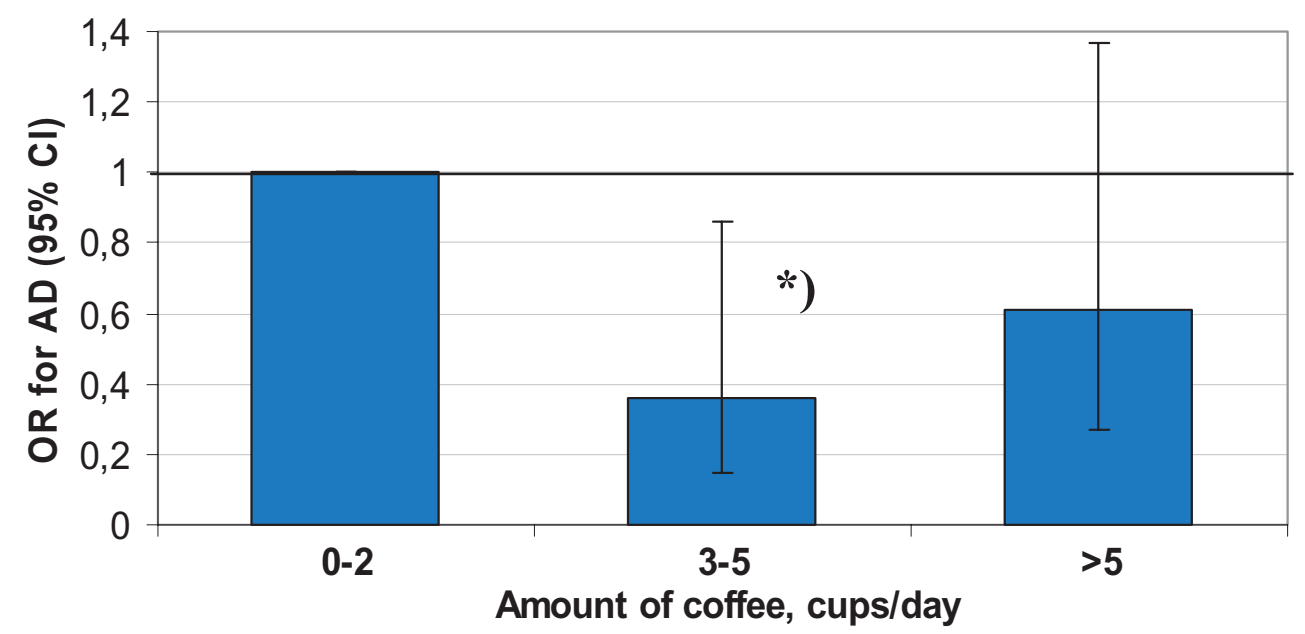

Fig. 2. Association between coffee drinking and Alzheimer's disease (model 2). $\left.{ }^{*}\right) p \leqslant 0.05$.

$38.5 \%$ consumed high ( $>5$ cups) amounts of coffee, and $15.9 \%$ consumed low ( $0-2$ cups) amounts of coffee. The majority of the participants $(60.5 \%)$ did not drink tea, and four fifths of tea drinkers consumed 1-2 cups per day. Persons with low coffee consumption were somewhat older at the midlife examination and more educated compared to those with higher coffee consumption. There were fewer men in the moderate coffee consumption group than in the other two groups. At midlife, the high coffee consumers had the highest serum total cholesterol levels and highest frequency of smoking. At late-life, the low coffee consumers had the highest occurrence of dementia and $\mathrm{AD}$, and the highest scores on the Beck depression scale.

Moderate coffee drinkers had a 65-70\% decreased risk of dementia and a $62-64 \%$ decreased risk of $A D$ compared with low coffee consumers. Adjustments for several confounders did not change the results. Model 1 was adjusted for midlife age, gender, education, follow-up time and community of residence. Model 2 was adjusted additionally for midlife smoking, SBP, serum total cholesterol, BMI, and physical activity. Model 3 was adjusted additionally for the ApoE $\varepsilon 4$ allelic status, the presence of late-life myocardial infarction (MI)/stroke/diabetes mellitus (DM), and Beck depressive scale. There was no dose-response between coffee drinking and the risk reduction of dementia and AD. When we rerun the analyses for dementia including diagnoses from the patient records for the nonparticipants in the follow-up, moderate coffee drinkers had a 59-60\% decreased risk for dementia compared to the low coffee consumers. Tea consumption (drinking 
$\geqslant 1$ cup of tea/day vs. not drinking) had no associations with dementia/AD (model 2: OR 1.04, 95\% CI $0.59-1.84$ for dementia, OR $0.91,95 \%$ CI $0.48-1.71$ for $\mathrm{AD}$, and $\mathrm{OR} 1.27,95 \% \mathrm{CI} 0.84-1.91$ for all the demented).

There were no significant multiplicative interactions between the ApoE genotype and coffee/tea drinking for the risk of dementia, but the results concerning coffee drinking were more pronounced among the ApoE $\varepsilon 4$ carriers than in non-carriers. In the analyses stratified by the ApoE $\varepsilon 4$ carrier status, OR for dementia among moderate coffee consumers compared to low consumers was 0.32 (95\% CI 0.11-0.92) among the ApoE $\varepsilon 4$ carrier and $0.44(0.12-1.55)$ among the noncarriers (model 2) [8]. Similarly, there were no significant multiplicative interactions between the gender and coffee/tea drinking for the risk of dementia and $\mathrm{AD}$, but the results concerning coffee drinking tended to be more pronounced among men.

\section{DISCUSSION}

Coffee drinking both at midlife and later in life has been related with a decreased risk of cognitive impairment, dementia and $\mathrm{AD}$ in several cohort studies. There is one study that supports coffee's favorable effects against dementia [8], two studies indicate a protective effect specifically against AD [8,12], and one study against cognitive impairment [13]. In addition, two studies had combined coffee and tea drinking as caffeine intake and indicated some positive effects on cognitive functioning $[15,16]$. For tea consumption, only one study has found positive effects against cognitive decline [19].

Our recent findings from the CAIDE study indicated that moderate coffee (3-5 cups/day) consumption at midlife was associated with a decreased risk of dementia and AD by about $65 \%$ in late-life. Tea consumption, however, showed no association with dementia or AD in the CAIDE-study population.

\section{Strengths and limitations of the previous studies}

There are several strengths in the previous studies: a population-based design, large samples, in many of them relatively long follow-up times, and adjustments for several confounding factors. The studies have also limitations: assessments for cognition have varied and, e.g., in the Finnish Twin Cohort Study [14], cognitive status was measured by using a validated tele- phone interview questionnaire. Further, five out of nine studies $[12,15,16,18,19]$ had relatively short follow-up times, and thus sub-clinical dementia may have affected how coffee and/or tea drinking was reported. Additionally, tea drinking was relatively rare in some populations (e.g., in the CAIDE study) making statistical power low. Further, most of the studies did not make any distinction between filtered, boiled or instant coffee. Thus, differences between tea and coffee and different types of coffee need to be further studied in cohorts with available data.

Reliance on self-report for data on coffee/tea drinking may constitute a limitation, although we do not believe that this would have lead to systematic errors in reporting coffee/tea drinking habits. Even though analyses were adjusted for several confounding factors, it is not possible to completely exclude the possibility of residual confounding due to measurement error in the assessment of confounding factors, or the potential role of some unmeasured factors. It is for example possible that moderate coffee drinking is related with otherwise healthy and social lifestyle that may confer part of the protective effects. On the other hand, among persons not drinking coffee/drinking very little coffee, some medical conditions (e.g., high blood pressure) may be overrepresented and may negatively affect cognitive functions. Other lifestyle and vascular risk factors may also partly explain the U-shaped association between coffee drinking and dementia suggested by the CAIDE study. Persons drinking larger amounts of coffee $(>5$ cups/day) had higher cholesterol values and were more often smokers than persons drinking less coffee, and even if we adjusted for these factors we cannot totally exclude some residual confounding. Further studies are needed to investigate possible dose-response effects and also effect modification by gender, ApoE genotype, and other lifestyle and vascular factors.

\section{Possible mechanisms}

Coffee is a complex mixture of chemicals including among others caffeine, chlorogenic acid, and diterpenes cafestol and kahweol [20]. Caffeine is a natural alkaloid, and has the highest existence in coffee among dietary products. Coffee is also a rich source of many other constituents that may contribute to its biological activity, including, for example, potassium, niacin, magnesium- and antioxidant substances, such as tocopherols and phenol chlorogenic acid (the ester of caffeic acid and quinic acid) [21]. Additionally, cafestol and kahweol are natural constituents of coffee 
beans, and have been associated with an increased risk of high serum total and LDL cholesterol concentrations in some observational studies [22]. However, the brewing method may affect to the cholesterol-raising effect of coffee; the diterpenes are mostly removed from coffee by filtering [21].

Interestingly, coffee drinking has been associated also with a decreased risk of type 2 diabetes [23], and one of the proposed mechanisms is that magnesium that is abundant in coffee would increase insulin sensitivity [24]. Diabetes in turn increases the risk of dementia. One pathway could be via insulin degrading enzyme (IDE) that degrades both insulin and amyloid- $\beta$ [25]. The insulin resistance in type 2 diabetes results has been associated with decreased amyloid- $\beta$ degradation.

Caffeine is a nonselective $\mathrm{A}_{1}$ and $\mathrm{A}_{2 a}$ adenosine receptor antagonist, and thereby it stimulates cholinergic neurons [26]. It has been shown in mice that both caffeine and adenosine $A_{2 A}$ receptor antagonists prevent amyloid- $\beta$ induced cognitive deficits [27]. Interestingly, a recent study suggested that caffeine reverses cognitive impairment and decreases brain amyloid- $\beta$ levels in aged AD mice [28]. Chronic caffeine administration has shown to have neuroprotective effects in the experimental models of hypoxia and ischemia, also related to caffeine action as adenosine receptor antagonist [29].

Further, the effect of coffee also may be due to its antioxidant capacity in circulating blood [30]. The most abundant polyphenol in coffee is chlorogenic acid (the ester of caffeic acid with quinic acid) and it is probably responsible for a major part of coffee antioxidants [30]. While vascular risk factors are so important in the development of dementia/AD [31], the role of coffee on vascular risk factors and outcomes is still unclear [32]. Unfiltered coffee increases cholesterol levels, but caffeine might have a positive effect on serum lipids [33].

In many of the previous longitudinal studies $[8,12$, $17,18]$, no association was found between tea drinking and the risk of dementia/AD. This could be due to lesser caffeine content in tea or the fact that other components than caffeine in coffee confer the protective effect.

Polyphenols, particularly flavonoids like catechins (flavan-3-ols), constitute the most interesting group of green tea leaf components [3]. Green tea contains more catechins - in vitro and in vivo strong antioxidants than black tea or oolong tea. In addition, its content of certain minerals and vitamins increases the antioxidant potential of this type of tea. Further studies are needed to clarify the role of different types of tea against dementia/AD.

\section{Conclusions}

It appears that moderate coffee consumption may decrease the risk of dementia/AD later in life. Given the large amount of coffee consumption globally, the results might have important implications for the prevention or delaying the onset of dementia/AD. Also, identification of mechanisms of how coffee exerts its protection against dementia/AD might help in the development of new therapies for these diseases.

\section{ACKNOWLEDGMENTS}

The study was supported by EVO-grant of Kuopio University Hospital (5772720), Academy of Finland grant 120676, EU grant QLK-2002-172, and the Yrjö Jahnsson Foundation. The funders had no role in study design; in the collection, analysis, and interpretation of data; in the writing of the report; and in the decision to submit the article for publication.

Authors' disclosures available online (http://www.jalz.com/disclosures/view.php?id=279).

\section{REFERENCES}

[1] Nehlig A (1999) Are we dependent upon coffee and caffeine? A review on human and animal data. Neurosci Biobehav Rev 23, 563-576.

[2] World Resources Institute/Earth Trends. Resource consumption: Coffee consumption per capita [online]. Available at: http://earthtrends.wri.org/searchable_db

[3] Cabrera C, Artacho R, Gimenez R (2006) Beneficial effects of green tea - a review. J Am Coll Nutr 25, 79-99.

[4] Smith A (2002) Effects of caffeine on human behavior. Food Chem Toxicol 40, 1243-1255.

[5] Santos C, Costa J, Santos J, Vaz-Carneiro A, Lunet N (2010) Caffeine intake and dementia: systematic review and metaanalysis. J Alzheimers Dis, in press.

[6] Vartiainen E, Puska P, Jousilahti P, Korhonen HJ, Tuomilehto J, Nissinen A (1994) Twenty-year trends in coronary risk factors in north Karelia and in other areas of Finland. Int J Epidemiol 23, 495-504.

[7] Kivipelto M, Helkala EL, Hänninen T, Laakso MP, Hallikainen M, Alhainen K, Soininen H, Tuomilehto J, Nissinen A (2001) Midlife vascular risk factors and late-life mild cognitive impairment: A population-based study. Neurology 56, 16831689.

[8] Eskelinen MH, Ngandu T, Tuomilehto J, Soininen H, Kivipelto M (2009) Midlife coffee and tea drinking and the risk of latelife dementia: A population-based CAIDE study. J Alzheimers Dis 16, 85-91.

[9] WHO MONICA Project Principal Investigators (1988) The world health organization MONICA project (monitoring trends and determinants in cardiovascular disease): A major international collaboration. J Clin Epidemiol 41, 105-114. 
[10] American Psychiatric Association (1994) Diagnostic and Statistical Manual of Mental Disorders, (4th edition), American Psychiatric Association, Washington DC

[11] McKhann G, Drachman D, Folstein M, Katzman R, Price D, Stadlan EM (1984) Clinical diagnosis of Alzheimer's disease: Report of the NINCDS-ADRDA work group under the auspices of department of health and human services task force on Alzheimer's disease. Neurology 34, 939-944.

[12] Lindsay J, Laurin D, Verreault R, Hébert R, Helliwell B, Hill GB, McDowell I (2002) Risk factors for Alzheimer's disease: A prospective analysis from the Canadian study of health and aging. Am J Epidemiol 156, 445-453.

[13] van Gelder BM, Buijsse B, Tijhuis M, Kalmijn S, Giampaoli S, Nissinen A, Kromhout D (2007) Coffee consumption is inversely associated with cognitive decline in elderly European men: The FINE study. Eur J Clin Nutr 61, 226-232.

[14] Laitala VS, Kaprio J, Koskenvuo M, Raiha I, Rinne JO, Silventoinen K (2009) Coffee drinking in middle age is not associated with cognitive performance in old age. Am J Clin Nutr 90, 640-646.

[15] van Boxtel MP, Schmitt JA, Bosma H, Jolles J (2003) The effects of habitual caffeine use on cognitive change: A longitudinal perspective. Pharmacol Biochem Behav 75, 921-927.

[16] Ritchie K, Carrière I, de Mendonça A, Portet F, Dartigues JF, Rouaud O, Barberger-Gateau P, Ancelin ML (2007) The neuroprotective effects of caffeine: A prospective population study (the Three City Study). Neurology 69, 536-545.

[17] Laurin D, Masaki KH, Foley DJ, White LR, Launer LJ (2004) Midlife dietary intake of antioxidants and risk of late-life incident dementia: The Honolulu-Asia Aging Study. Am J Epidemiol 159, 959-967.

[18] Dai Q, Borenstein AR, Wu Y, Jackson JC, Larson EB (2006) Fruit and vegetable juices and Alzheimer's disease: The Kame Project. Am J Med 119, 751-759.

[19] Ng TP, Feng L, Niti M, Kua EH, Yap KB (2008) Tea consumption and cognitive impairment and decline in older Chinese adults. Am J Clin Nutr 88, 224-231.

[20] Higdon JV, Frei B (2006) Coffee and health: A review of recent human research. Crit Rev Food Sci Nutr 46, 101-123.

[21] Ranheim T, Halvorsen B (2005) Coffee consumption and human health - beneficial or detrimental? - mechanisms for effects of coffee consumption on different risk factors for cardiovascular disease and type 2 diabetes mellitus. Mol Nutr Food Res 49, 274-284.
[22] Jee SH, He J, Appel LJ, Whelton PK, Suh I, Klag MJ (2001) Coffee consumption and serum lipids: A meta-analysis of randomized controlled clinical trials. Am J Epidemiol 153, 353-362.

[23] Tuomilehto J, Hu G, Bidel S, Lindstrom J, Jousilahti P (2004) Coffee consumption and risk of type 2 diabetes mellitus among middle-aged Finnish men and women. JAMA 291, 1213-1219.

[24] de Valk HW (1999) Magnesium in diabetes mellitus. Neth J Med 54, 139-146.

[25] Watson GS, Craft S (2003) The role of insulin resistance in the pathogenesis of Alzheimer's disease: Implications for treatment. CNS Drugs 17, 27-45.

[26] Fredholm BB, Battig K, Holmen J, Nehlig A, Zvartau EE (1999) Actions of caffeine in the brain with special reference to factors that contribute to its widespread use. Pharmacol Rev 51, 83-133.

[27] Dall'Igna OP, Fett P, Gomes MW, Souza DO, Cunha RA, Lara DR (2007) Caffeine and adenosine $\mathrm{A}_{2 \alpha}$ receptor antagonists prevent beta-amyloid (25-35)-induced cognitive deficits in mice. Exp Neurol 203, 241-245.

[28] Arendash GW, Mori T, Cao C, Mamcarz M, Runfeldt M, Dickson A, Rezai-Zadeh K, Tan J, Citron BA, Lin X, Echeverria V, Potter H (2009) Caffeine reverses cognitive impairment and decreases brain amyloid-beta levels in aged Alzheimer's disease mice. J Alzheimers Dis 17, 661-680.

[29] de Mendonça A, Sebastião AM, Ribeiro JA (2000) Adenosine: Does it have a neuroprotective role after all? Brain Res Rev 33, 258-274.

[30] Svilaas A, Sakhi AK, Andersen LF, Svilaas T, Ström EC, Jacobs DR, Ose L, Blomhoff R (2004) Intakes of antioxidants in coffee, wine, and vegetables are correlated with plasma carotenoids in humans. J Nutr 134, 562-567.

[31] Kivipelto M, Ngandu T, Laatikainen T, Winblad B, Soininen H, Tuomilehto J (2006) Risk score for the prediction of dementia risk in 20 years among middle aged people: A longitudinal, population-based study. Lancet Neurol 5, 735-741.

[32] Sudano I, Binggeli C, Spieker L, Lüscher TF, Ruschitzka F, Noll G, Corti R (2005) Cardiovascular effects of coffee: Is it a risk factor? Prog Cardiovasc Nurs 20, 65-69.

[33] Du Y, Melchert HU, Knopf H, Braemer-Hauth M, Gerding B, Pabel E (2005) Association of serum caffeine concentrations with blood lipids in caffeine-drug users and nonusers - results of German national health surveys from 1984 to 1999. Eur J Epidemiol 20, 311-316. 